\title{
Early larval morphology of the armed nylon shrimp Heterocarpus ensifer ensifer A. Milne-Edwards, 1881 (Decapoda, Caridea, Pandalidae) from laboratory culture
}

\author{
JOSÉ MARÍA LANDEIRA ${ }^{1,4}$, FERNANDO LOZANO-SOLDEVILLA ${ }^{1}$, EDUARDO ALMANSA $^{2}$ \\ \& JUAN IGNACIO GONZÁLEZ-GORDILLO ${ }^{3}$ \\ ${ }^{1}$ Departamento de Biología Animal, Facultad de Biología, Universidad de La Laguna, Spain \\ ${ }^{2}$ Instituto Español de Oceanografía, Santa Cruz de Tenerife, Spain \\ ${ }^{3}$ Centro Andaluz de Ciencia y Tecnología Marinas, Universidad de Cádiz, Spain \\ ${ }^{4}$ Corresponding autor. E-mail: jmlandei@ull.es
}

\begin{abstract}
The first four zoeal stages of the shrimp Heterocarpus ensifer ensifer were obtained under laboratory conditions. The morphology of each larval stage was described and illustrated in detail. The Heterocarpus's larval features fit into the characteristics of the family Pandalidae, and indicate a close relationship with the genus Plesionika.
\end{abstract}

Key words: Decapoda, Pandalidae, Heterocarpus ensifer ensifer, zoeal stages

\section{Introduction}

The family Pandalidae Haworth, 1825, currently composed by 22 recognized genera (De Grave et al., 2009), has a cosmopolitan distribution from littoral shores to more than $3000 \mathrm{~m}$ (Chace 1985). In the north Atlantic and Mediterranean Sea, this family is represented by the genera Bitias Fransen, 1990, Pantomus A. MilneEdwards, 1883, Heterocarpus A. Milne-Edwards, 1881, Chlorotocus A. Milne-Edwards, 1882, Atlantopandalus Komai, 1999, Dichelopandalus Caullery, 1896, Pandalina Calman, 1899, Stylopandalus Coutière, 1905, Pandalus Leach, 1814, Plesionika Bate, 1888 (Williams 1984; D’Udekem D'Acoz 1999). The larval morphology is still unknown for the first three genera while for the following five genera more accurate descriptions according to the modern standards are needed. Only Pandalus and Plesionika have detailed descriptions but only for few species.

Three species of the genus Heterocarpus are reported in the north east Atlantic Ocean and Mediterranean waters (D’Udekem D'Acoz 1999): H. ensifer ensifer A. Milne-Edwards, 1881, H. grimaldii A. MilneEdwards \& Bouvier, 1900 and H. laevigatus Bate, 1888. H. ensifer is an amphiatlantic species distributed in the western Atlantic from North Carolina to Brazil, including the Caribbean Sea and Gulf of Mexico (LozanoÁlvarez et al. 2007), in the eastern Atlantic from southwest and Mediterranean Spanish coast to Gabon in the western Africa and in the archipelagos of Azores, Madeira, Canary Islands and Cape Verde (D'Udekem D'Acoz 1999; D'Udekem D'Acoz et al. 2001). This pandalid shrimp has also been reported across the IndoWest Pacific, but their taxonomic identity is uncertain (Crosnier \& Forest 1973). This species not only is a species that inhabits sandy-muddy bottoms over the continental and island slopes (88-821 m depth) (González et al. 2001) but also can show a pelagic distribution during juvenile stages (González 1995). The ovigerous females occur from January to December suggesting a year-round reproductive activity (González et al. 2001; Lozano-Álvarez et al. 2007). Frequently, tons of $H$. ensifer constitute the bycatch of the artisanal fishery of Plesionika narval and Plesionika edwardsii in Canary Island archipelago. However, experimental fishing with bottom traps has been carried out to ascertain the potential fishery resource of this species in the Canary Islands, Hawaii and Cape Verde (Gooding 1984; Santana et al. 1997; González \& Tariche 2009). 
Although Heterocarpus is the second most speciose genus of the family Pandalidae with 27 species (De Grave et al. 2009) and has a potential fishery interest (Holthuis 1980) the larval morphology is still completely unknown (González-Gordillo et al. 2001). In order to increase the knowledge of the larval morphology of family Pandalidae, the present study describes in detail the first four larval stages of Heterocarpus ensifer ensifer from laboratory reared material, and compares its morphology with that of other known pandalid larvae.

\section{Material and methods}

Ovigerous females of $H$. ensifer ensifer were captured by bottom traps on muddy bottoms of the island shelf off NE Tenerife, Canary Islands (28 $32.00^{\prime} \mathrm{N}-16^{\circ} 07.20^{\prime} \mathrm{W}$ ) from a depth of $320 \mathrm{~m}$ on 13 March 2007. The sampling was performed within the frame of the deep fisheries research project (REDECA) on board B/O Pixape II. The shrimps were transported in coolers to the "Instituto Español de Oceanografía (IEO)" laboratory of Santa Cruz de Tenerife, where they were placed into a 10001 flow-through seawater tank and fed on frozen fish (Scomber spp.). Before hatching, on 19 March, two ovigerous females (with the embryos more developed) were isolated into 101 aquarium. One of them spawned on $20 \mathrm{March}$, but all the larvae died within $24 \mathrm{~h}$. On 22 March, the other female spawned and the most active larvae were placed into three 101 cylindro-conical grey tanks with aerated seawater, temperature of $21 \pm 1^{\circ} \mathrm{C}$ and natural photoperiod. Rearing procedure was based on Calado et al. (2003).

During the first two instars the larvae were fed a diet of Brachionus plicatilis, which were cultured with Chlorella sp., at a density of 20 individual per ml, while third and fourth instars were fed with Artemia sp. nauplii at a density of 15 individual per ml. Ten randomly selected larvae were sorted daily and preserved in $80 \%$ ethanol for drawing purposes. Before drawings, the larval tissues were partially digested with heated lactic acid and stained with Clorazol Black for improving the observation of larval structures (Landeira et al. 2009a). Drawings were carried out using interference phase microscope with attached camera lucida. Larval descriptions and setal counts followed the method proposed by Clark et al. (1998) and setal terminology was the same used for the larval description of Plesionika edwardsii (Landeira et al. 2009a) and of Plesionika narval (Landeira et al. 2009b) to facilitate comparison between both genera. Carapace length (CL) was measured from the tip of the rostrum to the posterior carapace margin. The sizes are given as the arithmetic mean $95 \%$ confidence intervals. Rostrum length/ frontal lobe length ratio (RS/FL) was done to show the decreasing length of the rostrum through larval development. The larval series was deposited in the "Museo de la Naturaleza y el Hombre (MNH)" in Santa Cruz de Tenerife, Spain (number DL/000736).

\section{Results}

Four larval stages of Heterocarpus ensifer ensifer were obtained for the first 17 days after hatching in the laboratory. The high mortality rate prevented the further culture and we decided to collect the few remaining larvae for taxonomic purposes. The first zoeal stage is completely described, while only the main differences of following larval stages are described in detail. Morphology of each larval stage and appendage setation are summarized in Table 1.

\section{Heterocarpus ensifer ensifer A.Milne-Edwards, 1881}

(Figures 1-5)

\section{First zoea}

Carapace (Figures 1A, E, H). Flattened; dorsomedian tubercle on anterior and posterior part of carapace; rostrum smooth, pointed downward and shorter than antennular peduncle length; 1 pterygostomian spine and 2 spines on anteroventral margin; sessile eyes. 
TABLE 1. Morphological and meristic features of zoeal stages of Heterocarpus ensifer ensifer. Setal groups on successive segments are separated by a comma and groups of setae on the same segment, or on different lobes of the same endite, are separated by a plus sign (+). RS, rostral spine; FL, frontal lobe; 6 and 5, length of 6 and 5 abdominal somites respectively; (-), absent; a, aesthetasc; c, spiniform seta; d, plumodenticulate seta; e, sparsely plumose seta; f, plumoserrulate seta; $\mathrm{h}$, sparsely hardy plumose seta; $\mathrm{j}$, spiny projection; L, laterally plumose seta; m, microtrichia; $\mathrm{n}$, plumose natatory seta; $p$, plumose seta; $r$, serrulate seta; s, simple seta; t, plumodenticulate cuspidate seta; v, spatulate seta; $x$, anal spine.

\begin{tabular}{|c|c|c|c|c|}
\hline & Zoea I & Zoea II & Zoea III & Zoea IV \\
\hline \multicolumn{5}{|l|}{ Carapace } \\
\hline Length (mm) & $0.760 \pm 0.031$ & $0.668 \pm 0.044$ & $0.745 \pm 0.047$ & $0.884 \pm 0.042$ \\
\hline Eyes & Sessile & stalked funnel-shaped & stalked funnel-shaped & stalked funnel-shaped \\
\hline Ratio RS/FL & 2 & 1.5 & $>1$ & $>1$ \\
\hline \multicolumn{5}{|l|}{ Antennule } \\
\hline Peduncle & 2 small tubercles & $2 \mathrm{p}$ & $1 p, 5 p, 4 p+6 p$ & $1 p+1 c+4 p, 1 p+5 p, 6 p+6 p$ \\
\hline Endopod & long plumose seta & long plumose seta & long plumose seta & long plumose seta \\
\hline Exopod & $3 a+1 p+1 v$ & $1 c+3 a+1 v+1 p$ & $1 p+(1 c+1 p+2 a)$ & $(1 p+1 a)+(1 p+1 a)$ \\
\hline \multicolumn{5}{|l|}{ Antenna } \\
\hline Peduncle & $1 \mathrm{c}$ & $1 \mathrm{c}$ & $1 \mathrm{c}$ & $1 \mathrm{c}$ \\
\hline Endopod & $1 c+1 p$ & $1 c+1 p$ & $1 \mathrm{c}+1 \mathrm{~s}$ & 0 \\
\hline Ratio end/exo & $1 / 2$ & $1 / 2$ & $<1 / 2$ & $<1 / 2$ \\
\hline Exopod & $2 \mathrm{p}+1 \mathrm{p}, 2 \mathrm{p}, 1 \mathrm{p}, 1 \mathrm{p}, 1 \mathrm{p}, 3 \mathrm{p}+1 \mathrm{~s}$ & $2 \mathrm{p}+1 \mathrm{p}, 2 \mathrm{p}, 1 \mathrm{p}, 1 \mathrm{p}, 1 \mathrm{p}, 3 \mathrm{p}+1 \mathrm{~s}$ & $3 p+1 p, 2 p, 1 p, 1 p, 3 p+1 s$ & $13 p+1 j+1 p$ \\
\hline \multicolumn{5}{|l|}{ Maxillule } \\
\hline Coxal endite & $1 \mathrm{~s}+5 \mathrm{~d}+1 \mathrm{p}$ & $1 \mathrm{~s}+5 \mathrm{~d}+1 \mathrm{p}$ & $1 \mathrm{~s}+5 \mathrm{~d}+1 \mathrm{p}$ & $1 \mathrm{~s}+5 \mathrm{~d}+1 \mathrm{p}$ \\
\hline Basial endite & $2 t+3 d$ & $4 t+3 d$ & $4 t+3 d$ & $4 t+3 d$ \\
\hline Endopod & $(1 \mathrm{~s}+1 \mathrm{e}+1 \mathrm{~h})+(1 \mathrm{e}+1 \mathrm{~h})+1 \mathrm{e}$ & $(1 \mathrm{~s}+1 \mathrm{e}+1 \mathrm{~h})+(1 \mathrm{e}+1 \mathrm{~h})+1 \mathrm{e}$ & $(1 \mathrm{~s}+1 \mathrm{e}+1 \mathrm{~h})+(1 \mathrm{e}+1 \mathrm{~h})+1 \mathrm{e}$ & $(1 \mathrm{~s}+1 \mathrm{e}+1 \mathrm{~h})+(1 \mathrm{e}+1 \mathrm{~h})+1 \mathrm{e}$ \\
\hline Exopod & 0 & 0 & 0 & 0 \\
\hline \multicolumn{5}{|l|}{ Maxilla } \\
\hline Coxal endite & $9 p+(2 L+2 p)$ & $11 p+(2 L+2 p)$ & $11 p+(1 L+3 p)$ & $11 p+(1 L+3 p)$ \\
\hline Basial endite & $(3 e+1 h+1 L)+(3 e+1 h+1 L)$ & $(3 e+1 h+1 L)+(3 e+1 h+1 L)$ & $(3 e+1 h+1 L)+(3 e+1 h+1 L)$ & $(3 e+1 h+1 L)+(3 e+1 h+1 L)$ \\
\hline Endopod & $3 e+(1 e+1 h)+1 h+1 h+2 e$ & $(2 e+1 h)+(1 e+1 h)+1 h+1 h+2 e$ & $\begin{array}{c}(2 e+1 h)+(1 e+1 h)+1 h+1 h+2 \\
e\end{array}$ & $(2 e+1 h)+(1 e+1 h)+1 h+1 h+2 e$ \\
\hline Exopod & $5 \mathrm{p}$ & $5 p$ & $7 \mathrm{p}$ & $9 p$ \\
\hline \multicolumn{5}{|l|}{1 Maxilliped } \\
\hline Coxa & $1 e+(2 s+1 p)+1 p+(1 h+1 e)$ & $1 e+(2 e+1 p)+1 h+(1 h+1 e)$ & $1 e+(2 e+1 p)+1 h+(1 h+1 e)$ & $1 e+(2 e+1 p)+1 p+(1 h+1 e)$ \\
\hline Basis & $(2 h+1 e)+(1 h+2 e)+3 e+3 e$ & $(2 h+1 e)+(1 h+2 e)+4 e+4 e$ & $(2 h+1 e)+(1 h+2 e)+4 e+4 e$ & $(2 h+1 e)+(1 h+2 e)+4 e+4 e$ \\
\hline Endopod & $3 \mathrm{e}, 1 \mathrm{e}, 1 \mathrm{r}+1 \mathrm{e}, 1 \mathrm{~s}+3 \mathrm{r}$ & $3 \mathrm{e}, 1 \mathrm{e}, 2 \mathrm{e}, 1 \mathrm{~s}+3 \mathrm{r}$ & $3 \mathrm{e}, 1 \mathrm{e}, 2 \mathrm{e}, 1 \mathrm{~s}+3 \mathrm{r}$ & $3 \mathrm{e}, 1 \mathrm{e}, 2 \mathrm{e}, 1 \mathrm{~s}+3 \mathrm{r}$ \\
\hline Exopod & $1 n+3 n$ & $1 n+4 n$ & $1 n+4 n$ & $1 n+4 n$ \\
\hline \multicolumn{5}{|l|}{2 Maxilliped } \\
\hline Coxa & 1e & 1e & 1e & $1 \mathrm{e}$ \\
\hline Basis & $1 e+2 e+3 e+3 e$ & $1 e+2 e+3 e+3 e$ & $1 e+2 e+3 e+3 e$ & $1 e+2 e+3 e+3 e$ \\
\hline Endopod & $3 \mathrm{e}, 1 \mathrm{e}, 1 \mathrm{e}+1 \mathrm{r}, 1 \mathrm{~s}+4 \mathrm{r}$ & $3 \mathrm{e}, 1 \mathrm{e}, 0,1 \mathrm{e}+1 \mathrm{r}, 1 \mathrm{~s}+4 \mathrm{r}$ & $3 e, 1 e, 0,1 e+1 r, 1 s+5 r$ & $3 e, 1 e, 0,1 \mathrm{e}+1 \mathrm{r}, 1 \mathrm{~s}+5 \mathrm{r}$ \\
\hline Exopod & $2 n+3 n$ & $2 n+4 n$ & $2 n+4 n$ & $2 n+4 n$ \\
\hline \multicolumn{5}{|l|}{3 Maxilliped } \\
\hline Coxa & 0 & 0 & 0 & 0 \\
\hline Basis & $1 e+1 e+2 e$ & $1 e+1 e+2 e$ & $1 e+1 e+2 e$ & $1 e+1 e+2 e$ \\
\hline Endopod & $2 \mathrm{e}, 1 \mathrm{~s}, 2 \mathrm{r}, 1 \mathrm{~s}+3 \mathrm{r}$ & $2 \mathrm{e}, 1 \mathrm{e}, 0,2 \mathrm{r}, 1 \mathrm{~s}+3 \mathrm{r}$ & $2 \mathrm{e}, 1 \mathrm{e}, 1 \mathrm{e}, 2 \mathrm{r}, 1 \mathrm{~s}+4 \mathrm{r}$ & $2 \mathrm{e}, 1 \mathrm{e}, 1 \mathrm{e}, 1 \mathrm{e}+2 \mathrm{r}, 1 \mathrm{~s}+4 \mathrm{r}$ \\
\hline Exopod & $2 n+3 n$ & $2 n+4 n$ & $2 n+4 n$ & $1 n+2 n+4 n$ \\
\hline
\end{tabular}


TABLE 1. (continued)

\begin{tabular}{lcccc}
\hline & Zoea I & Zoea II & Zoea III & Zoea IV \\
\hline 1 Pereiopod & - & biramous bud & biramous bud & 0 \\
Coxa & - & - & - & $1 \mathrm{e}+1 \mathrm{e}+2 \mathrm{e}$ \\
Basis & - & - & - & - \\
Endopod & - & - & - & $2 \mathrm{~s}, 1 \mathrm{~s}, 0,2 \mathrm{r}, 1 \mathrm{~s}+2 \mathrm{r}$ \\
Exopod & - & - & - & biramous bud \\
2 Pereiopod & - & - & - & - \\
3 Pereiopod & - & - & 3 & $1 \mathrm{x}$ \\
Abdomen & - & - & 0 & 3 \\
Ratio 6/5 & - & - & $2 \mathrm{p}$ & 0 \\
Uropod & - & - & $6 \mathrm{p}$ & $9 \mathrm{p}$ \\
Protopod & - & - & $(1 \mathrm{~s}+7 \mathrm{f})+(1 \mathrm{~s}+7 \mathrm{f})$ & $3 \mathrm{p}+9 \mathrm{p}+1 \mathrm{~s}$ \\
Endopod & $(1 \mathrm{~L}+6 \mathrm{f})+(1 \mathrm{~L}+6 \mathrm{f})$ & $(1 \mathrm{~L}+7 \mathrm{f})+(1 \mathrm{~L}+7 \mathrm{f})$ & $(3 \mathrm{~s}+5 \mathrm{f})+(3 \mathrm{~s}+5 \mathrm{f})$ \\
Exopod & & & & 0 \\
Telson & & & & \\
\hline
\end{tabular}

Antennule (Figure 2A). Peduncle unsegmented, bears terminally 2 small tubercles. Endopod as a long plumose setae. Exopod present distally 1 plumose seta, 1 spatulate seta and 3 aesthetascs.

Antenna (Figure 2E). Peduncle unsegmented, with 1 sharp spiniform seta distally. Endopod unsegmented, with 1 long plumose seta and 1 spiniform seta. Exopod broad and distally 6-segmented with 11 marginal plumose setae and 1 simple seta on apex.

Mandible. Asimetrical, without palp; incisor process and molar process well developed.

Maxillule (Figure 3A). Coxal endite unilobed with 1 simple seta, 5 denticulate setae, 1 plumose seta and marginal microtrichias; basial endite with 2 plumodenticulate cuspidate setae, 3 plumodenticulate seta, and marginal microtrichias. Endopod unsegmented, 3-lobed with 1 simple, 1 sparsely plumose and 1 sparsely hardly plumose setae in the first lobe, 1 sparsely plumose and 1 sparsely hardly plumose setae in the median lobe and 1 sparsely plumose seta in the distal lobe. Exopod absent.

Maxilla (Figure 3D). Coxal endite bilobed with 9 plumose setae and 4 setae ( 2 sparsely laterally and 2 plumose setae) respectively; basial endite bilobed with 3 sparsely plumose, 1 sparsely hardly plumose and 1 laterally plumose setae in each lobe. Endopod unsegmented and 5-lobed with: 3 sparsely plumose setae; 1 sparsely plumose seta and 1 sparsely hardly plumose setae; 1 sparsely hardly plumose seta; 1 sparsely hardly plumose seta; 2 sparsely plumose setae and microtrichias respectively. Exopod with 5 long plumose setae and microtrichias.

First maxilliped (Figure 3F). Coxal endite with 7 setae forming 4 groups with 1 sparsely plumose seta, 2 simple and 1 plumose setae, 1 plumose seta, 1 hardly sparsely plumose and 1 sparsely plumose setae; basial endite with 12 setae in 4 groups, first two groups with 2 sparsely hardly plumose setae and 1 sparsely seta respectively and two last groups with 3 sparsely plumose setae respectively). Endopod 4-segmented with 3 sparsely plumose setae, 1 sparsely plumose seta, 1 sparsely plumose and 1 serrulate setae, 1 simple and 3 serrulate setae in the distal segment. Exopod unsegmented bearing 1 subterminal and 3 terminal plumose natatory setae.

Second maxilliped (Figure 4A). Coxal endite with 1 sparsely plumose seta; basial endite with 9 sparsely plumose setae arranged as 1,2,3,3. Endopod 4-segmented with 3 sparsely plumose setae, 1 sparsely plumose seta, 1 sparsely plumose and 1 serrulate setae, and in the distal segment with 1 simple and 4 serrulate setae. Exopod unsegmented with 2 subterminal and 3 terminal plumose natatory setae.

Third maxilliped (Figure 4E). Coxal endite without seta; basial endite with 4 sparsely plumose setae. Endopod 4-segmented, longer than exopod and with 2 sparsely plumose setae, 1 sparsely plumose seta, 2 serrulate setae and 1 simple plus 3 serrulate setae in the distal segment. Exopod unsegmented with 2 subterminal and 3 terminal plumose natatory setae. 


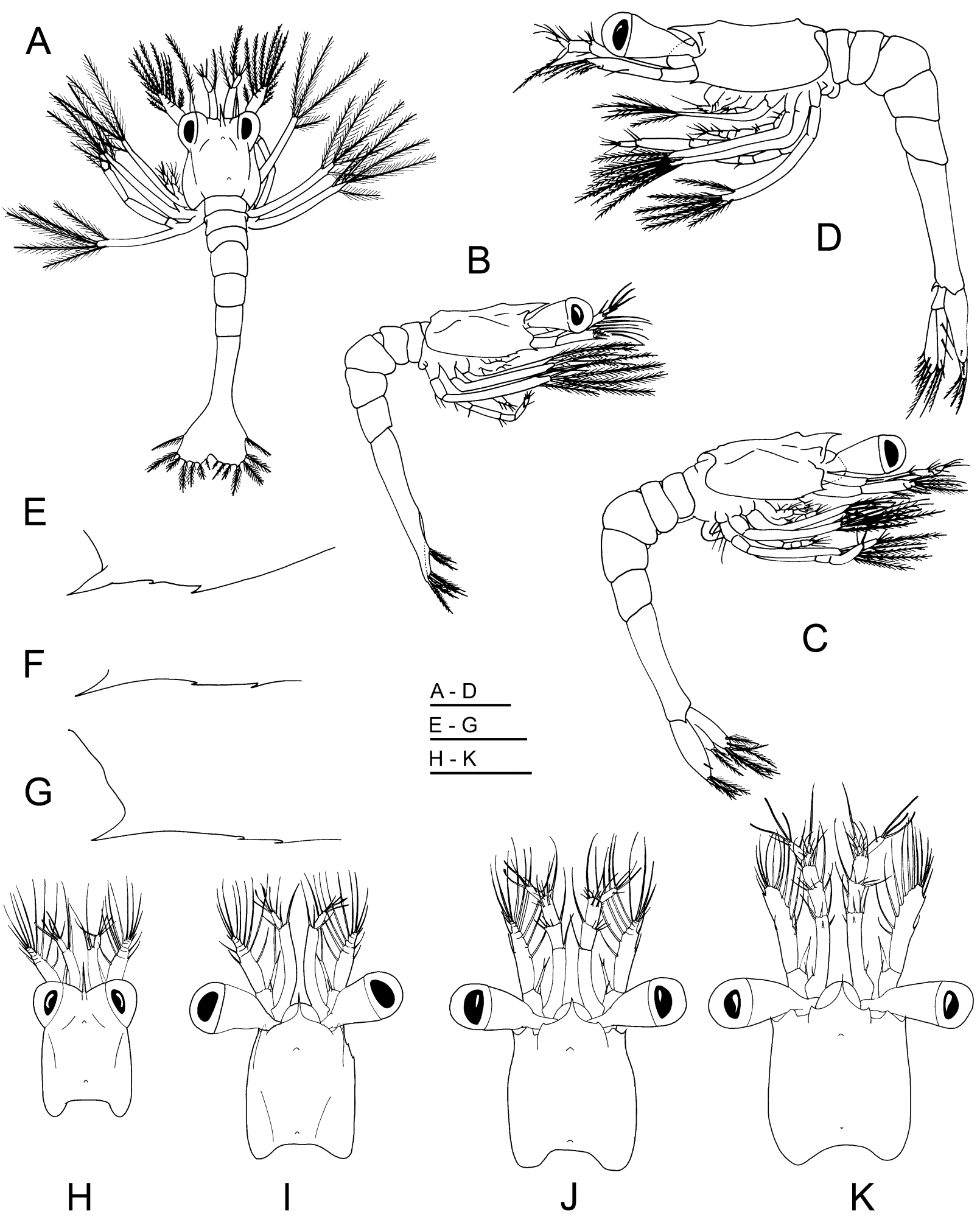

FIGURE 1. Heterocarpus ensifer ensifer, dorsal view: A, zoea I; lateral view: B, zoea II; C, zoea III; D, zoea IV; ventral margin of carapace: E, zoea I; F, zoea III; G, zoea IV; carapace dorsal view: H, zoea I; I, zoea II; J, zoea III; K, zoea IV. Scale bars: A-D, $\mathrm{H}-\mathrm{K}=500 \mu \mathrm{m} ; \mathrm{E}-\mathrm{G}=100 \mu \mathrm{m}$.

Pereiopods. Absent.

Abdomen (Figures 1A, 5E). Five somites without spines or setae.

Pleopods. Absent.

Uropods. Absent. 
Telson (Figure 5E). Triangular, broad posteriorly, with $7+7$ setae (inner 6 plumoserrulate, outer 1 laterally plumose seta). A row of spinules on the distal margin and around the base of setae.
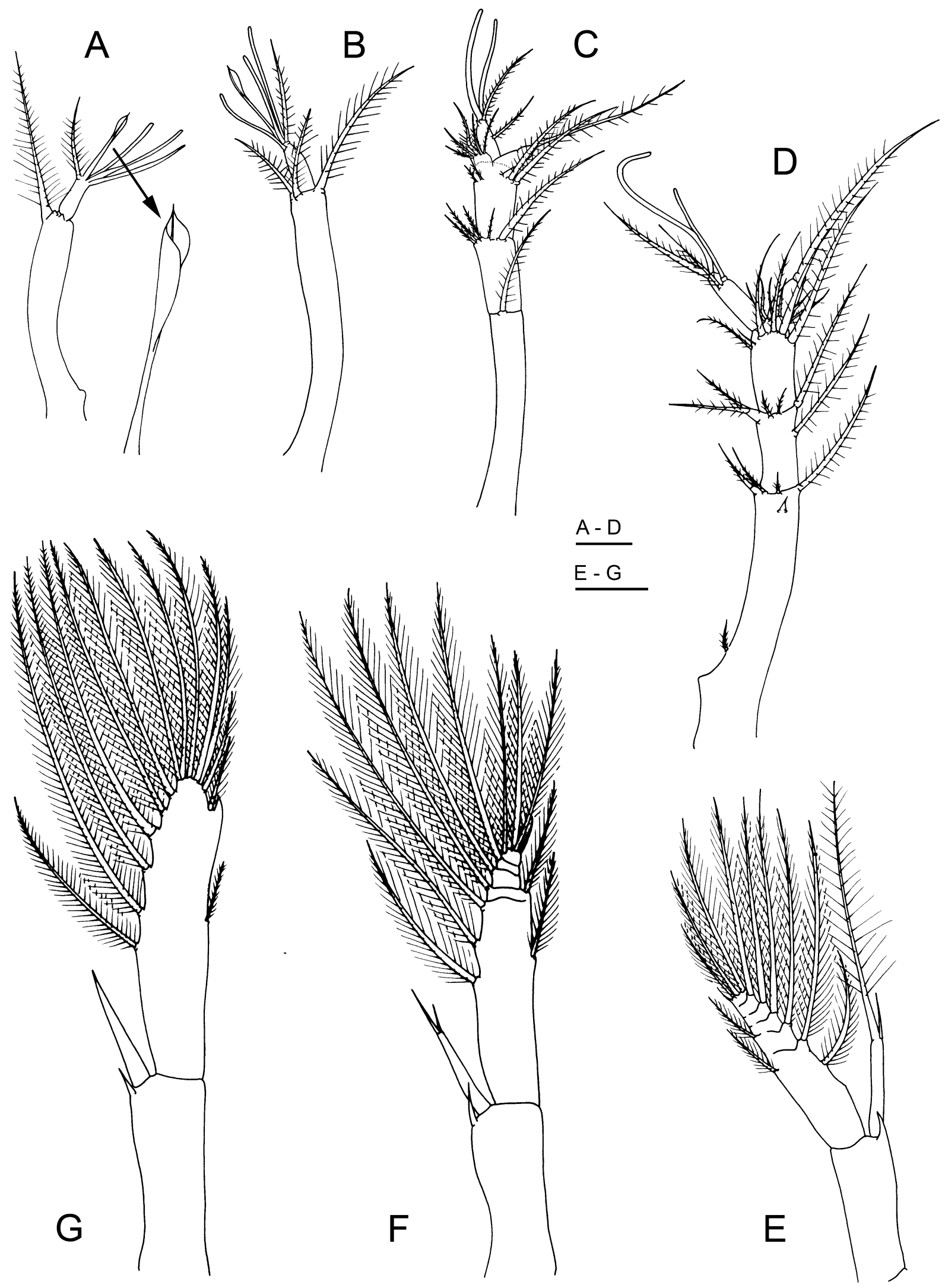

FIGURE 2. Heterocarpus ensifer ensifer, antennule: A, zoea I; B, zoea II; C, zoea III; D, zoea IV; antenna: E, zoea I; F, zoea III; G, zoea IV. Scale bars: $100 \mu \mathrm{m}$. 

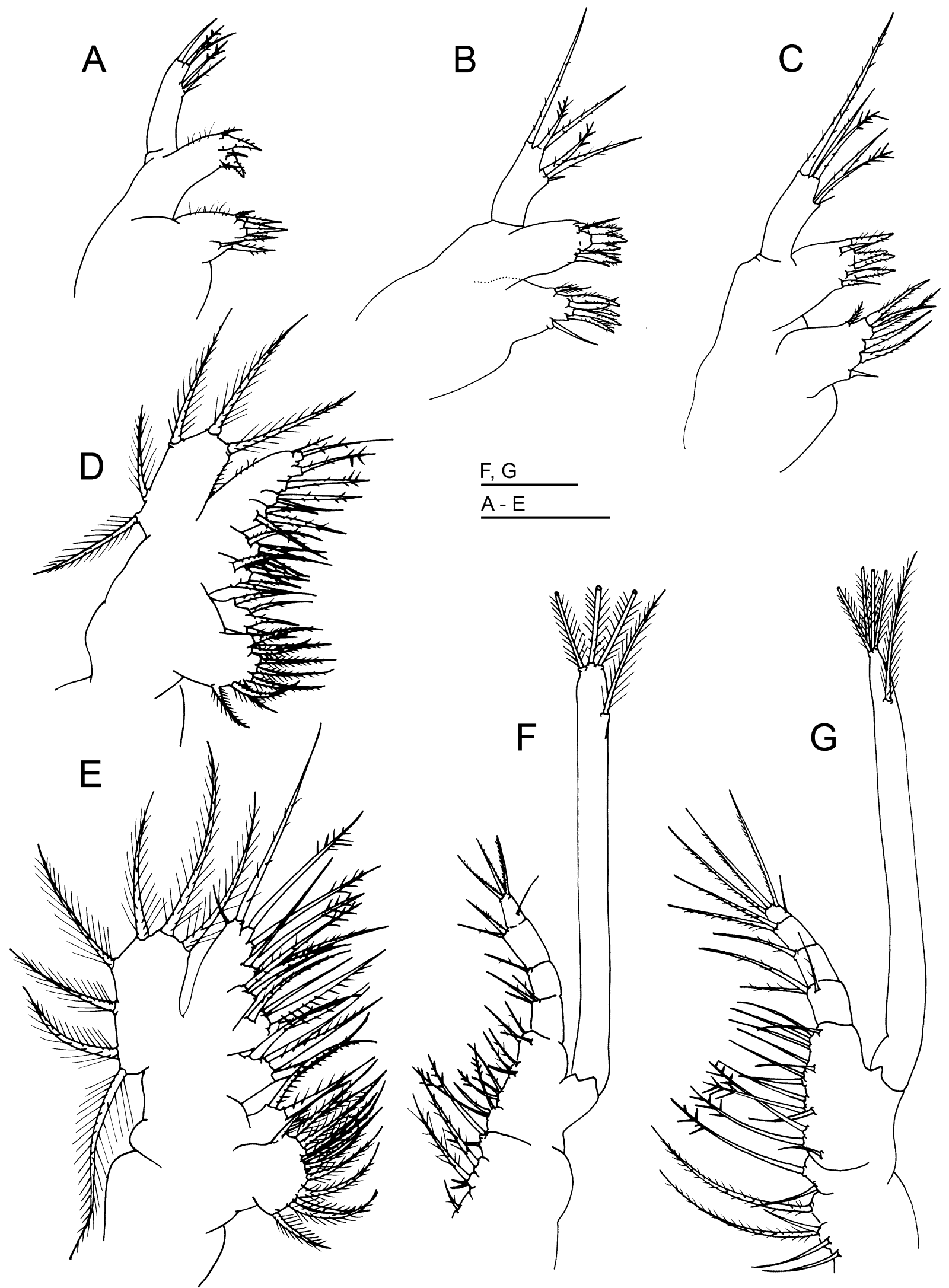

FIGURE 3. Heterocarpus ensifer ensifer, maxillule: A, zoea I; B, zoea II; C, zoea IV; maxilla: D, zoea I; E, zoea III; first maxilliped: F, zoea I; G, zoea IV. Scale bars: $100 \mu \mathrm{m}$. 

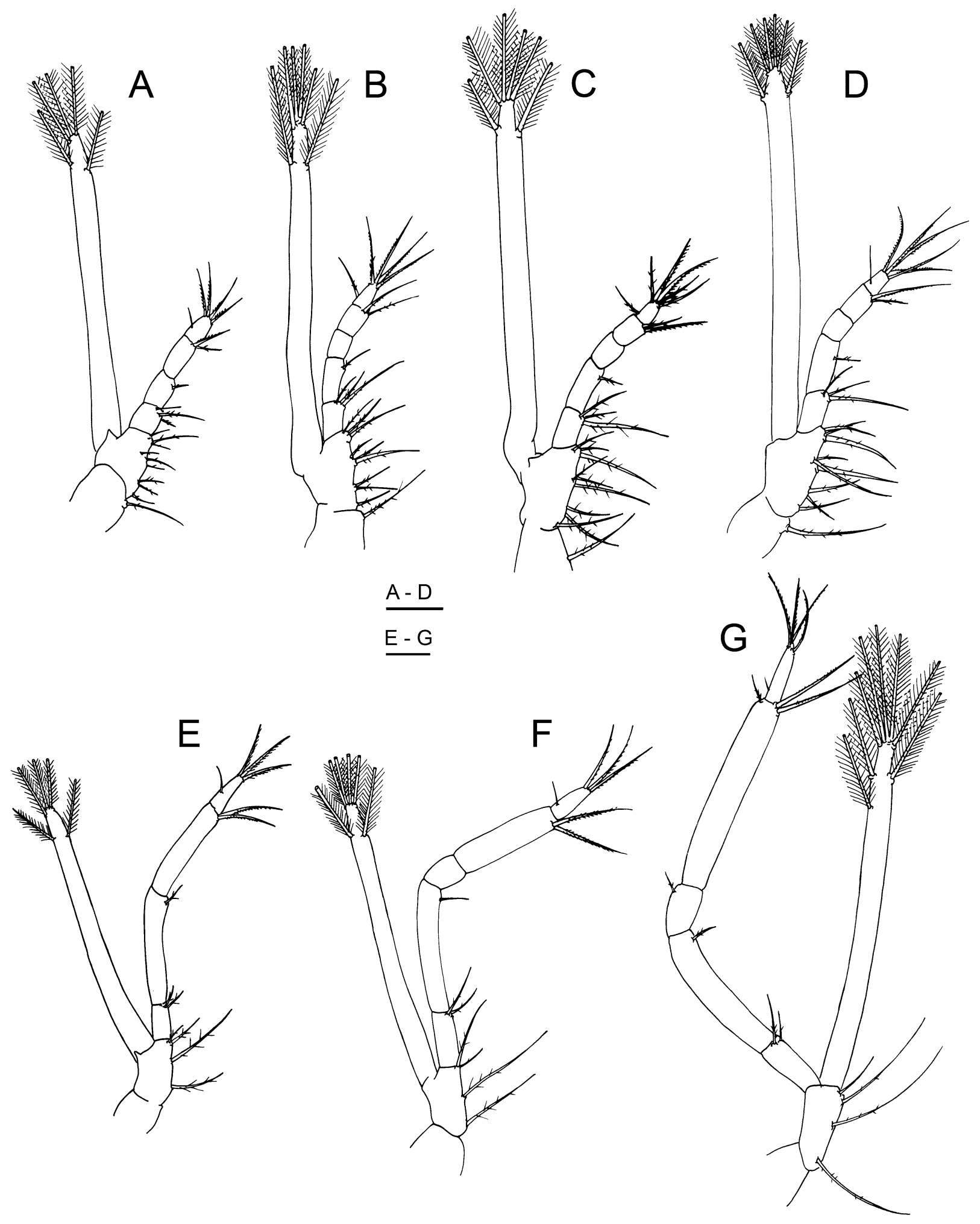

FIGURE 4. Heterocarpus ensifer ensifer, second maxilliped: A, zoea I; B, zoea II; C, zoea III; D, zoea IV; third maxilliped: E, zoea I; F, zoea II; G, zoea IV. Scale bars: $100 \mu \mathrm{m}$.

\section{Second zoea}

Carapace (Figures 1B, I). Eyes stalked and funnel-shaped; rostrum shorter than Zoea I; 1 pair of small supraorbital spines.

Antennule (Figure 2B). Peduncle unsegmented with 2 terminal plumose setae. Endopod as long plumose seta. Exopod bears 1 spiniform seta, 1 plumose seta, 1 spatulate seta and 3 aesthetascs. 


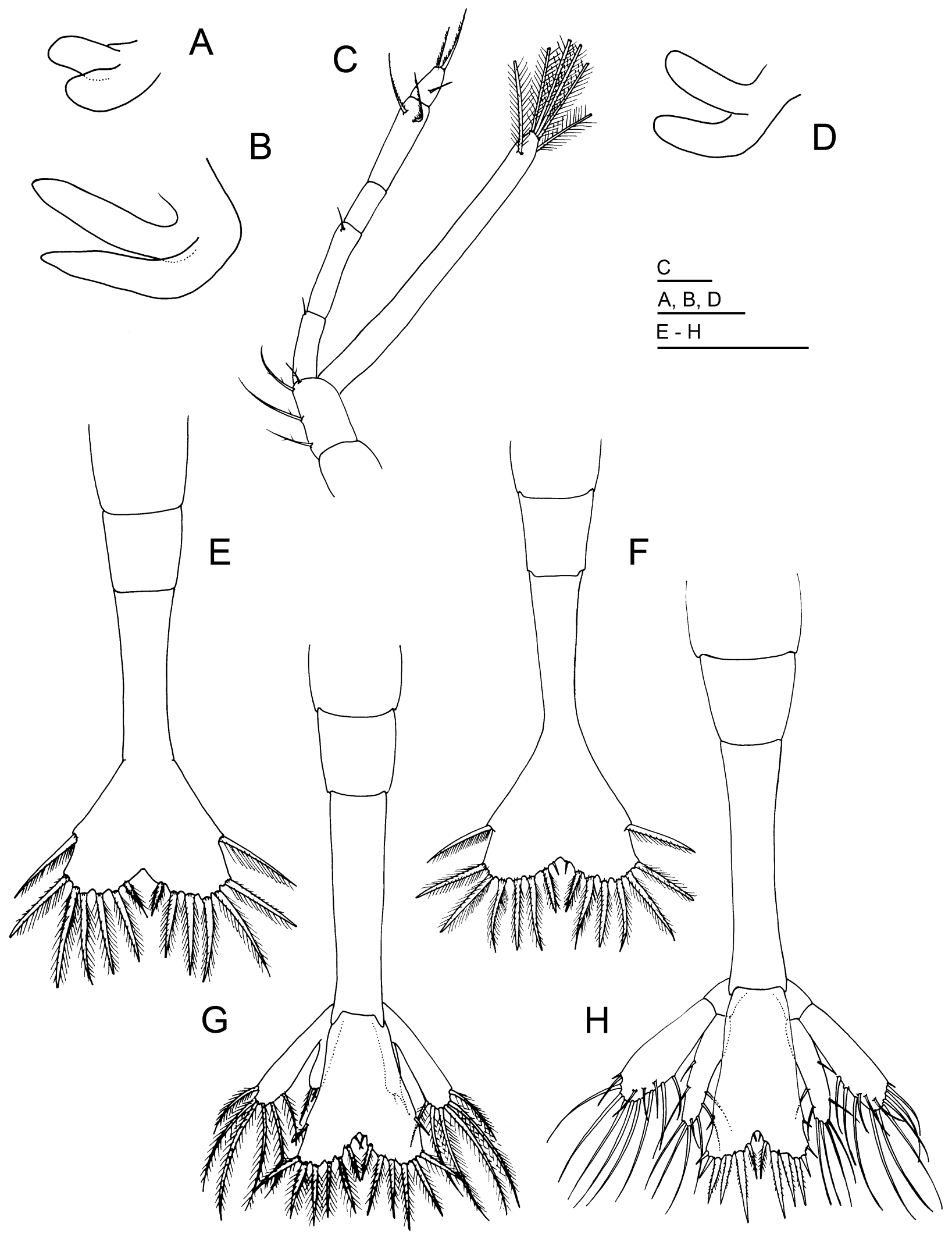

FIGURE 5. Heterocarpus ensifer ensifer, first pereiopod: A, zoea II; B, zoea III; C, zoea IV; second pereiopod: D, zoea IV; pleon: E, zoea I; F, zoea II; G, zoea III; H, zoea IV. Scale bars: A - D = $100 \mu \mathrm{m}$; E - H = $500 \mu \mathrm{m}$.

Antenna. Unchanged.

Mandible. Unchanged. 
Maxillule (Figure 3B). Basial endite with 4 plumodenticulate cuspidate setae plus 3 plumodenticulate seta; otherwise unchanged.

Maxilla . Coxal endite bilobed with 11 plumose setae and 2 laterally plumose plus 2 plumose setae respectively; otherwise unchanged.

First maxilliped. Basial endite with four groups of setae arranged as $3+3+4+4$. Exopod unsegmented bearing 1 subterminal and 4 terminal plumose natatory setae; otherwise unchanged.

Second maxilliped (Figure 4B). Coxal and basial endites without changes. Endopod 5-segmented with setae arranged as 3,1,0,1+1,1+4. Exopod unsegmented with 2 subterminal and 4 terminal plumose natatory setae.

Third maxilliped (Figure 4F). Coxa and basis unchanged. Endopod 5-segmented with setae arranged as $2,1,0,2,1+3$. Exopod with 2 subterminal and 4 terminal plumose natatory setae.

First pereiopod (Figure 5A). Biramous bud.

Second to fifth pereiopod. Absent.

Pleopods. Absent.

Abdomen (Figures 1B, 5F). Unchanged.

Uropods. Absent.

Telson (Figure 5F). Triangular, with $8+8$ setae (inner 7 plumoserrulate, outer 1 laterally plumose setae).

\section{Third zoea}

Carapace (Figures 1C, F, J). Rostrum shorter than previous stages but longer than frontal lobe; otherwise unchanged.

Antennule (Figure 2C). Peduncle 3-segmented: proximal segment with 1 long plumose seta; the medial segment with 5 terminal plumose setae ( 1 long and 4 short); distal segment with 4 plumose setae ( 2 long and 2 short) and with 6 plumose setae distributed over the margin of small process. Endopod unsegmented with 1 long plumose seta. Exopod with 2 plumose setae and 2 aesthetascs plus 1 spiniform seta.

Antenna (Figure 2F). Peduncle unchanged. Endopod unsegmented with 1 spiniform and 1 simple setae. Exopod 5-segmented with 11 marginal plumose setae and 1 simple seta on apex.

Mandible. Unchanged.

Maxillule. Unchanged.

Maxilla (Figure 3E). Exopod with 7 plumose setae; otherwise unchanged.

First maxilliped. Unchanged.

Second maxilliped (Figure 4C). Endopod 5-segmented with setae arranged as 3,1,0,2,1+5; otherwise unchanged.

Third maxilliped. Endopod 5-segmented with setae arranged as 2,1,1,2,1+4 respectively. Exopod with 2+4 plumose natatory setae; otherwise unchanged.

First pereiopod (Figure 5B). Biramous bud.

Second to fifth pereiopod. Absent.

Pleopods. Absent.

Abdomen (Figures 1C, 5G). Sixth abdominal somite separated from telson. Otherwise unchanged.

Uropods (Figure 5G). Biramous. Endopod rudimentary with 2 plumose setae. Exopod well developed with 6 plumose setae.

Telson (Figure 5G). With $8+8$ setae, the outermost pair of setae with a subterminal position.

Fourth zoea

Carapace (Figures 1D, G, K). Rostrum still smooth, otherwise unchanged.

Antennule (Figure 2D). Peduncle 3-segmented: basal segment with 1 proximal plumose seta, 1 strong spiniform seta plus 1 long and 3 short plumose setae in the distal edge; medial segment with 1 long plumose seta and 4 plumose setae plus 1 long plumose seta; distal segment with $6+6$ plumose setae arranged in 2 groups. Endopod unsegmented with 1 long plumose seta on the posterior end. Exopod with 2 plumose setae and 2 aesthetascs (one of them longer and wider). 
Antenna (Figure 2G). Endopod unsegmented without setae. Exopod unsegmented with 13 plumose setae in the inner marginal, 1 spiny projection on apex and 1 plumose seta in the outer margin; otherwise unchanged.

Mandible. Unchanged.

Maxillule (Figure 3C). Unchanged.

Maxilla. Exopod with 9 long plumose setae and microtrichias; otherwise unchanged.

First maxilliped (Figure 3G). Unchanged.

Second maxilliped (Figure 4D). Unchanged.

Third maxilliped (Figure 4G). Endopod 5-segmented with setae arranged as 2,1,1,1+2,1+4 respectively; Exopod with $1+2+4$ plumose natatory setae.

First pereiopod (Figure 5C). Coxa without seta; basis with 1+1+2 sparsely plumose setae. Endopod 5segmented, with 1,1,0,2,1+2. Exopod unsegmented, as long as endopod, with 2 subterminal and 4 terminal plumose natatory setae.

Second pereiopod (Figure 5D). Biramous bud.

Third to fifth pereiopod. Absent.

Abdomen (Figures 1D, 5H). Anal spine presents; otherwise unchanged.

Pleopods. Absent.

Uropods (Figure 5H). Protopod without seta. Endopod well developed with 9 plumose setae. Exopod with 9 terminal and 3 subterminal plumose setae plus 1 simple seta on the outer apex.

Telson (Figure 5H). Almost rectangular shaped; 1 pair of lateral simple setae, on the posterior margin with 5 pair of plumoserrulate setae and 2 pair of outer simple setae.

\section{Discussion}

The family Pandalidae has a worldwide distribution and includes numerous species with important fishery interest (Holthuis 1980) but the knowledge of larval morphology is still scarce. For example, Heterocarpus is the second most speciose genus of the family Pandalidae with 27 species (De Grave et al. 2009) but the larval morphology is still completely unknown, (González-Gordillo et al. 2001). In addition, other genera distributed in North Atlantic waters such as Bitias and Pantomus have no larval information either.

On the other hand, several authors have described the larval morphology pandalid species based on planktonic material and from larvae reared in the laboratory from eggs of know parentages. In this sense, Heegard (1969) gave a less detailed description of the zoea I of Chlorotocus crassicornis, which constitutes the only available larval information of the genus. The morphology of Dichelopandalus, Pandalina, Stylopandalus, Pandalus and Atlantopandalus (as Pandalus propinqvus) larvae were established mainly by Lebour (1940) and Pike \& Williamson (1964) while, Plesionika larvae has been described recently by Landeira et al. (2009 a, b). The present description of Heterocarpus ensifer ensifer fills one gap in larval knowledge of this family.

In general, the larval morphology of $H$. ensifer ensifer agrees with the Pandalidae's features: dorsal connection between carapace and abdomen almost make 180 angle, eye peduncle narrowed at base, antennular peduncles strongly concave, rostrum well developed since first stage, supraorbital spines present and cephalotorax with two dorsal protuberances (Thatje \& Bacardit 2000; dos Santos \& González-Gordillo 2004). Moreover, Heterocarpus larvae showed the spatulate seta in the antennular exopod in zoea I and II which were previously found in Pandalina by Barnich (1996) and in Plesionika by Landeira et al. (2009a, b). We suspect that this peculiar seta could be common in the family Pandalidae, but must be found and confirmed in the rest of genera, to establish its phylogenetic importance.

The sequence of larval development of $H$. ensifer ensifer follows the same pattern of the most caridean larvae, being easily to recognize the first four larval stages: zoea I having sessile eyes, abdomen with five somites, pleopods and uropods absent; zoea II showing mobile eyes; zoea III having the abdomen with six somites and uropods (endopod rudimentary); and zoea IV with pleopods absent, antennal exopod not 
segmented and endopod of uropods functional (dos Santos \& González-Gordillo 2004). In this respect, the presence of undeveloped first and second pereiopods, the absence of third pereiopods and pleopods in zoea IV of $H$. ensifer ensifer suggest a long larval series of zoeal stages, but probably shorter than $P$. edwardsii and $P$. narval because the first and second pereiopods appear one stage earlier in H. ensifer ensifer (Landeira et al. 2009a, b).

The present description allows distinguishing $H$. ensifer ensifer from other pandalids which share their geographic distribution range. For example, Chlorotocus differs greatly from Hetocarpus in having six abdominal somites from zoea I (Heegaard 1969), while Dichelopandalus could be distinguished by the presence of one pair of lateral spines in the fifth abdominal somite (Lebour, 1940). On the other hand, dissimilarities between Pandalina and Stylopandalus from Heterocapus are found regarding the funnelshaped eyes (Lebour 1940; Pike \& Williamson 1964); indeed Heterocarpus present the typical Plesionika's eyes while Pandalina-Stylopandalus's eyes are quasi-globe shaped. Plesionika and Heterocarpus seem very close genera, sharing several features, such as: presence of long rostral spine in zoea I-II stages (although longer in Plesinika), long and slim sixth abdominal somite, presence of row of spinules along the distal margin of telson and the same setation pattern in the most of appendices. In turn, Heterocarpus ensifer ensifer can be distinguished from Plesionika edwardsii and P. narval by setation of the endite basial of the maxilla, because $H$. ensifer ensifer presents two groups of 5 setae while $P$. edwardsii has only 4 setae in each group. In zoea I-II Plesionika shows 4 setae in the coxal endite of the first maxilliped while Heterocarpus have 7. Another difference between these genera is the presence of 3 sparsely plumose setae in the endite basial of the first pereiopod in Plesionika while Heterocarpus have 4 setae. In addition, H. ensifer ensifer shows an anal spine from zoea IV, while they are absent in Plesionika species. Concerning the anteroventral spines of carapace, $P$. narval show three spines while H. ensifer ensifer and $P$. edwardsii have two spines (although they disappear from zoea II on in the last species).

On the other hand, the pandalid larvae collected in planktonic samples and initially assigned to Procletes Bate (1888) and Atlantocaris Ortmann (1893) and later included into Heterocarpus by Gurney \& Lebour (1941) have not been compared with the H. ensifer ensifer larvae described in the present study because they seem more developed, probably near decapodid stage.

From a phylogenetic point of view the position of the genus Heterocarpus remains unclear. In this sense, Christoffersen (1989) proposed a controversial classification through manual cladistic analysis on 21 genera, in which the genus Heterocarpus was elevated to family level forming an own new family Heterocarpidae. However, the recent updated classifications of Crustacea, (Martin \& Davis 2001) and of Decapoda (De Grave et al. 2009) pointed out that the Christoffersen's classification has had little following in the carcinological community. Indeed, they opted to not recognize the changes for now due to the use of questionable characters and the lack of diagnoses of the new taxa. The larval morphology could provide valuable information to relate different pandaloids taxa. The use of larval morphology to establish similarities between decapods have previously been used by Rice (1980), obtaining interesting results for brachyuran larvae.

\section{Acknowledgements}

The authors want to dedicate this study to the memory of Dr. Ignacio Jos Lozano Soldevilla, who passed away on 29 December of 2008. We would like to thank his constant interest in our pandalid larval studies, providing ovigerous females and valuable advices. This work was partially funded by project REDECA (CICYT, CTM2005-07712-C03-01/MAR) and supported by the "Formación de Personal Investigador, FPI" (JML grant number BES-2005-10960) and by the "Ramón y Cajal Research Program" to JIG-G both from Spanish Science and Technology Ministry and FEDER funds. 


\section{References}

Barnich, R. (1996) The larvae of the Crustacea Decapoda (Excl. Brachyura) in the plankton of the French Mediterranean coast. PhD thesis, Göttingen, Cuvillier Verlag. 189 pp.

Bate, C.S. (1888) Report of the Crustacea Macrura collected by H.M.S. Callenger during the years 1873-76. Report of the scientific results or the Voyage of H.M.S. Challenger, Zoology 24, XC+1-942.

Calado, R., Narciso, L., Morais, S., Rhyne, A.L. \& Lin, J. (2003) A rearing system for the culture of ornamental decapod crustacean larvae. Aquaculture, 218, 329-339.

Clark, P.F., Calazans, D.K. \& Pohle, G.W. (1998) Accuracy and standardization of brachyuran larval descriptions. Invertebrate Reproduction and Development, 33, 127-144.

Chace, F.A. (1985) The Caridean shrimps (Crustacea: Decapoda) of the Albatross Philippine Expedition, 1907-1910, Part 3: Families Thalassocarididae and Pandalidae. Smithsonian Contributions to Zoology, 411, 1-143.

Christoffersen, M.L. (1989) Phylogeny and classification of the Pandaloidea (Crustacea, Caridea). Cladistics, 5, 259274.

Crosnier, A. \& Forest, J. (1973) Les crevettes profondes de'l Atlantique Oriental Tropical. Faune Tropical (ORSTOM), $19,1-409$.

D’Udekem D'Acoz, C.D. (1999) Inventaire et distribution des crustacés décapodes de l'Atalantique nord-oriental, de la Méditerraée et des eaux continentales adjacentes au nord de $25^{\circ}$ N. Patrimoines naturels (M.N.H.N./S.P.N.) 40, 1383.

D’Udekem D’Acoz, C.D., Pinho, M.R., Melo, O., Gonçalves, J. \& Martins, H.R. (2001) New records and notes on little known shrimps (Crustacea, Decapoda) from Azorean waters. Arquipélago. Life and Marine Sciences, 18, 61-64.

De Grave, S., Pentcheff, N.D., Ahyong, S.T., Chan, T-Y., Crandall, K.A., Dworschak, P.C., Felder, D.L., Feldmann, R.M., Fransen, C.H.J.M., Goulding, L.Y.D., Lemaitre, R., Low, M.E.Y., Martin, J.W., Ng Peter, K.L., Schweitzer, C.E., Tan, S.H., Tshudy, S.H. \& Wetzer, R. (2009) A classification of living and fossil genera of decapod Crustaceans. Raffles Bulletin of Zoology (Suplement 21), 1-109.

dos Santos, A. \& González-Gordillo, J.I. (2004) Illustrated key for the identification of the Pleocyemata (Crustacea: Decapoda) zoeal stages, from the coastal region of south-western Europe. Journal of the Marine Biological Association of the United Kingdom, 84, 205-227.

González, J.A. (1995) Catálogo de Crustáceos Decápodos de Las Islas Canarias. Santa Cruz de Tenerife: Turquesa Ed., $282 \mathrm{pp}$.

González, J.A., Quiles, J.A., Tuset, V.M., García-Díaz, M.M. \& Santana, J.I. (2001) Data on the family Pandalidae around the Canary Islands, with first record of Plesionika antigay (Caridea). Hydrobiologia, 449, 71-76.

González, J.A. \& Tariche, O. (2009) Una mirada sobre la biodiversidad marina y base para su gestión sostenible. Recursos pesqueros potenciales de profundidad de Cabo Verde. Presidencia del Gobierno de Canarias/ Fundación Universitaria de Las Palmas. Las Palmas de Gran Canaria. 1-176

González-Gordillo, J.I., dos Santos, A. \& Rodríguez, A. (2001) Checklist and annotated bibliography of decapod crustacean larvae from the Southwestern European coast (Gibraltar Strait area). Scientia Marina, 65 (4), $275-305$.

Gooding, R.M. (1984) Trapping surveys for the deepwater caridean shrimps, Heterocarpus laevigatus and H. ensifer, in the Northwestern Hawaiian Islands. Marine Fisheries Review. 46(2), 18-26.

Gurney, R. \& Lebour, M.V. (1941) On the larvae of certain Crustacea Macrura, mainly from Bermuda. Journal of the Linnean Society of London, 41, 89-181.

Heegaard, P. (1969) The first larval stage of Chlorotocus crassicornis (Decapoda, Pandalidae). Crustaceana, 17, 151158.

Holthuis, L.B. (1980) FAO species catalogue. Shrimps and prawns of the world. An annotated catalogue of species of interest to fisheries. FAO Fisheries Circular 125(1), 1-271.

Landeira, J.M., Lozano-Soldevilla, F. \& González-Gordillo, J.I. (2009a) Morphology of first seven larval stages of the striped soldier shrimp, Plesionika edwardsii (Brandt, 1851) (Crustacea: Decapoda: Pandalidae) from laboratory reared material. Zootaxa, 1986, 51-66.

Landeira, J.M., Lozano-Soldevilla, F. \& González-Gordillo, J.I. (2009b) Description of the first five larval stages of Plesionika narval (Fabricius, 1787) (Crustacea, Decapoda, Pandalidae) obtained under laboratory conditions. Zootaxa, 2206, 45-61.

Lebour, M.V. (1940) The larvae of the Pandalidae. Journal of Marine Biological Association of the United Kingdom, 24, 239-252.

Lozano-Álvarez, E., Briones-Fourzán, P., García A. \& Vázquez-Bader, A. (2007) Relative growth and size at first maturity of deep water shrimp, Heterocarpus ensifer (Decapoda, Pandalidae) from the southern Gulf of Mexico. Crustaceana, 80, 555-568.

Martin, J.W. \& Davis, G.E. (2001) An updated classification of the Recent Crustacea. Natural History Museum of Los Angeles County, Contributions in Science, 39, 1-124. 
Ortmann, A.E. (1893) Decapoden und Schizopoden. Plankton-Expedition der Humboldt-Stiftung. Wissenschaftliche Ergebnisse, 2, 1-120.

Pike, R.B. \& Williamson, D.I. (1964) The larvae of some species of Pandalidae (Decapoda). Crustaceana, 6, $265-284$.

Rice, A.L. (1980) Crab zoeal morphology and its bearing on the classification of the Brachyura. Transactions of the Zoological Society of London, 35, 271-424.

Santana, J.I., González, J.A., Lozano, I.J. \& Tuset, V.M. (1997) Life history of Plesionika edwardsii (Crustacea, Decapoda, Pandalidae) around the Canary Islands, eastern central Atlantic. South African Journal of Marine Science, 18, 39-48.

Saunders, W.B. \& Hastie, L.C. (1992) Remote camera and trapping survey of the deep-water shrimps Heterocarpus laevigatus and $H$. ensifer and the geryonid crab Chaceon granulatus in Palau. Marine Fish Research, 54, 15-25.

Thatje, S. \& Bacardit, R. (2000) Larval development of Austropandalus grayi (Cunningham, 1871) (Decapoda, Caridea, Pandalidae) from the southwestern Atlantic Ocean. Crustaceana, 73, 609-628.

Williams, A.B. (1984) Shrimps, Lobsters, and Crabs of the Atlantic Coast of the Eastern United States, Maine to Florida. Smithsonian Institution Press, Washington, D. C., 1-550. 